\title{
Recruitment and retention strategies for public sector optometrists in KwaZulu-Natal Province, South Africa
}

\begin{tabular}{|c|c|}
\hline $\begin{array}{l}\text { Authors: } \\
\text { Prasidh Ramsc } \\
\text { Pirindha Gove } \\
\text { Kovin Naidoo }\end{array}$ & $\begin{array}{l}\text { nd }^{1,2} \text { (1) } \\
\text { nder }^{2,3,4} \\
3,4\end{array}$ \\
\hline $\begin{array}{l}\text { Affiliations: } \\
{ }^{1} \text { Department } \\
\text { Sciences, Cape } \\
\text { University of T } \\
\text { South Africa }\end{array}$ & $\begin{array}{l}\text { Ophthalmic } \\
\text { Peninsula } \\
\text { echnology, }\end{array}$ \\
\hline $\begin{array}{l}{ }^{2} \text { African Vision } \\
\text { Institute, Univ } \\
\text { KwaZulu-Nata }\end{array}$ & $\begin{array}{l}\text { Research } \\
\text { ersity of } \\
\text { South Africa }\end{array}$ \\
\hline $\begin{array}{l}{ }^{3} \text { Brien Holden } \\
\text { Institute, Durb } \\
\text { South Africa }\end{array}$ & $\begin{array}{l}\text { Vision } \\
\text { an, }\end{array}$ \\
\hline $\begin{array}{l}{ }^{4} \text { Discipline of } \\
\text { University of } \\
\text { South Africa }\end{array}$ & $\begin{array}{l}\text { ptometry, } \\
\text { waZulu-Natal, }\end{array}$ \\
\hline $\begin{array}{l}\text { Correspondin } \\
\text { Prasidh Ramsc } \\
\text { ramsonp@cp }\end{array}$ & $\begin{array}{l}\text { author: } \\
\text { n, } \\
\text { t.ac.za }\end{array}$ \\
\hline $\begin{array}{l}\text { Dates: } \\
\text { Received: } 20 \mathrm{~J} \\
\text { Accepted: } 17 \\
\text { Published: } 20\end{array}$ & $\begin{array}{l}\text { an. } 2016 \\
\text { une } 2016 \\
\text { Sept. } 2016\end{array}$ \\
\hline $\begin{array}{l}\text { How to cite th } \\
\text { Ramson P, Go } \\
\text { Naidoo K. Rec } \\
\text { retention strat } \\
\text { sector optome } \\
\text { KwaZulu-Nata } \\
\text { South Africa. } \\
\text { Health. 2016; } \\
\text { http://dx.doi. } \\
\text { aveh.v75i1.34 }\end{array}$ & $\begin{array}{l}\text { is article: } \\
\text { ender } P \text {, } \\
\text { uitment and } \\
\text { egies for public } \\
\text { trists in } \\
\text { Province, } \\
\text { fr Vision Eye } \\
5(1), \text { a349. } \\
\text { rg/10.4102/ }\end{array}$ \\
\hline $\begin{array}{l}\text { Copyright: } \\
\text { (C) } 2016 \text {. The A } \\
\text { Licensee: AOS } \\
\text { is licensed unc } \\
\text { Creative Comr } \\
\text { Attribution Lic }\end{array}$ & $\begin{array}{l}\text { uthor(s). } \\
\text { S. This work } \\
\text { er the } \\
\text { nons } \\
\text { ense. }\end{array}$ \\
\hline Read online: & \\
\hline 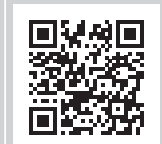 & $\begin{array}{l}\text { Scan this QR } \\
\text { code with your } \\
\text { smart phone or } \\
\text { mobile device } \\
\text { to read online. }\end{array}$ \\
\hline
\end{tabular}

Background: In South Africa, there is a paucity of optometrists serving the needs of the larger public sector. KwaZulu-Natal is one of the most densely populated provinces and home to several of the poorest districts. Despite an optometry school in the province, and with a lack of compulsory community service for new graduates, more optometrists are needed to serve the public sector. While studies on the recruitment and retention of medical and allied health professionals have been conducted, limited evidence exists on work trends of public sector optometrists.

Methods: A cross-sectional study design using both quantitative and qualitative data collection methods was used. All public sector optometrists and local district health co-ordinators in the province were contacted, with an $80 \%$ (41 out of 51) and $75 \%$ (9 out of 12 ) response rate, respectively. Questionnaires containing demographic, recruitment, retention and open-ended questions were distributed by post, fax and email and via an online survey to both groups. Telephonic interviews were also conducted using semi-structured techniques. Frequency distributions, Fisher's exact test and odds ratios were used to statistically describe the demographic data, while qualitative responses were recorded and analysed for commonly occurring themes.

Results: The present public sector optometry workforce comprises mainly young (73\%), black $(70 \%)$, women $(66 \%)$. They chose to work in the public sector to 'make a difference' and were attracted by 'good working hours' and 'job security'. Fifty-three percent of optometrists work in the public sector due to a study bursary, for which there was a statistically significant association for race $(p=0.01)$, gender $(p=0.05)$ and background origin $(p=0.05)$. To aid their retention in public service, improved salaries, career progression, recognition, improved management relations and improved instrumentation were ranked highest by these optometrists.

Conclusion: The demographic profile of presently serving public sector optometrists poses many human resource (HR) challenges and opportunities. Universities should pay attention to rural origin of students and provide exposure to rural clinical experiences during study. Departments of Health use study bursary incentives to recruit optometrists, but need to consider financial and non-financial incentives for their retention. At hospital level, a responsive HR management system should be implemented with emphasis on career management, recognition, improving infrastructure and supporting professional development.

\section{Introduction}

The World Health Organisation (WHO) estimates there are 59.2 million health workers globally ${ }^{1}$; however, their distribution is not proportional to healthcare needs. For example, Canada and the United States have $37 \%$ of the world's health workforce with $10 \%$ of the global disease burden while Africa, in contrast, has more than a quarter (> 25\%) of the world's disease burden but has access to only $3 \%$ of health workers. The migration of health workers from Africa to developed nations also poses a threat to service delivery in Africa with one-fifth of all African-born doctors and one-tenth of all African-born professional nurses living and working overseas. ${ }^{2}$ It is predicted that a shortage of health workers will impact on meeting the Millennium Development Goals, ${ }^{1,2}$ while the WHO estimates that a further $7.2 \mathrm{~m}$ health workers are needed to improve universal health coverage. ${ }^{3}$ To prevent a mass exodus of health workers, employers should look to attract the appropriate candidates and provide enabling environments to keep them satisfied in their places of work.

Note: This article is partially based on the author's thesis of the degree of Master of Optometry in the Discipline of Optometry at the Faculty of Health Sciences, University of KwaZulu-Natal, South Africa, with supervisor Prof. K. Naidoo, received December 2014, available here: http://researchspace.ukzn.ac.za/xmlui/bitstream/handle/10413/13060/Ramson_Prasidh_2014.pdf?sequence=1\&isAllowed=y 


\section{Recruitment and retention of the health workforce}

Recruitment refers to the process of attracting applicants who comply with the criteria of a position to be filled in a company. ${ }^{4}$ While this may apply for corporates, attention must be paid to previously described recruitment factors that influence a health worker's choice to serve in the public sector.

Medical students, of rural origin, are most likely to choose careers in rural areas after graduation as systematic studies have shown. ${ }^{5}$ While gender profiles of the rural Human Resources for Health (HRH) workforce has historically been largely male workforce, ${ }^{6}$ recent data have found a larger proportion of female workforce. ${ }^{7}$ The influence of friends and family in medical career choice is also common. ${ }^{8}$ Community exposure and community-based education programmes, along with previous exposure to rural service in undergraduate training is known to influence final choices of where to practice. ${ }^{9,10}$

Retention refers to efforts by an organisation to create and maintain a working environment that supports the present staff in remaining with the organisation. It also requires a combination of good management, effective human resource (HR) motivation and innovative methods. ${ }^{11}$ Retention strategies to keep HRH within an enabling environment, offer financial and non-financial incentives to allow workers to continue a long and productive relationship. Financial incentives for retention may include service-linked scholarships, loanrepayment programmes and bursaries; however, few studies have revealed the efficacy and outcome of these incentives ${ }^{12}$ or their impact on geographic distribution of health professionals. ${ }^{13}$ In South Africa, the Scarce Skills Allowance, Rural allowance (RA) and Occupational Specific Dispensation (OSD) financial incentives to retain health workers have been implemented inconsistently across different health professions with variable success.

Non-financial incentives for retention refer to those incentives that do not involve a transfer of monetary value (or equivalent) to the health worker ${ }^{14}$ but includes career and HR management (HRM), continuous professional development (CPD) and infrastructure and good management, among others. Career management is the process of 'planning the advancement of individuals within an organisation in accordance with the organisational needs and objectives'. ${ }^{4}$ For healthcare professionals in rural areas, career progression is deemed important for improved salary, chances of promotion and educational improvement. ${ }^{10}$ Career management needs should be situated within a larger HRM system and include key aspects like workforce planning, workplace conditions and performance management.

The purpose of CPD is to 'assist health professionals to maintain and acquire new and updated levels of knowledge, skills and ethical attitudes' ${ }^{\prime 15}$ The effect of CPD on improved practice patterns and better patient outcomes are sometimes questionable due to lack of proper evaluation and posttraining follow-up. ${ }^{16}$ Infrastructure and enabling work environments are also important in attracting and retaining staff in middle- to low-income countries ${ }^{17}$ Poor management (related to staff welfare, work performance and recognition) was a demotivating factor for sub-Saharan health workers. ${ }^{18}$ Good working environment, ${ }^{19}$ personal support and recognition were found to have a positive motivating effect on health workers. ${ }^{20}$

\section{Global blindness prevention}

The prevalence of blindness globally in 2010 was $32.4 \mathrm{~m}^{21}$ with at least $4.8 \mathrm{~m}$ people residing in sub-Saharan Africa. ${ }^{22}$ It is predicted that these numbers will increase should necessary interventions not be implemented to provide basic eye health screening, detection and treatment by eye health professionals. ${ }^{23}$

In 1998 the WHO, in partnership with the International Agency for the Prevention of Blindness, launched the VISION 2020: Right to Sight programme. ${ }^{24}$ It sought to mobilise all eye health assets, including private and public professionals, academic institutions, professional bodies, non-governmental and governmental agencies, in a concerted effort to eradicate avoidable blindness by the year 2020. VISION 2020 identified and targeted five main causes of avoidable blindness that constitute $80 \%$ of the world's blind, namely, cataract, onchocerciasis, trachoma, refractive error, low vision and childhood blindness. Key components in the programme are to meet the challenges of HRs, infrastructure and disease control. For planning purposes, HRs for eye health service provision are prescribed per million population. Using this ratio, one optometrist is recommended per 250000 people for developing and resource-limited countries..$^{25}$

\section{Optometry in South Africa}

In 1994, the South African government inherited a disparate healthcare system with an inequitable distribution of services. As part of its Restructuring and Development Programme, the District Health System (DHS) was adopted to deliver broad-based and equitable healthcare. In the DHS, Primary Health Care is the main vehicle to provide healthcare access for all. Based on the complexity of cases and the need for further investigation, patients are referred to subsequently higher levels of care. ${ }^{26}$ While the South African government's health policy has the DHS as a cornerstone, various services, most notably eye care, have been poorly defined.

The Health Professions Council of South Africa reports 3464 registered optometrists (private and public sector). ${ }^{27}$ Four universities produce an average of 200 graduates annually, but without compulsory community service and limited public sector posts there is a limited direct pathway for optometrists into the public sector, which serves more than $80 \%$ of the population. ${ }^{28}$ The present optometry curriculum caters insufficiently for community and rural health exposure, while the lure to earn foreign currency further affects the 
retention of optometrists within South Africa. ${ }^{29}$ Historically, the slow response of government in providing full-time posts further discourages optometrists from entering the public sector, except on a part-time basis or for compulsory CPD credit.

In 2007, 74 optometrists, supported by Private-Public Partnerships and Non-Governmental Organisations, served in the public sector in South Africa. ${ }^{30}$ While there has been an increase in the number of provincial posts created over the last 5 years, with anecdotal reports stating there are currently about 300 public sector optometrists in South Africa, they appear to be insufficient to accommodate the backlog of existing and incident cases. With fewer than $20 \%$ of South Africa's $51.8 \mathrm{~m}$ population subscribing to some form of medical aid or health insurance, this leaves approximately $41 \mathrm{~m}$ people reliant on the public healthcare service.

Medium- to long-term strategies to build public sector resources would include legislating compulsory community service and integrating an expanded public health approach into the undergraduate curriculum. Presently, compulsory community service is applied for some healthcare professionals but has been delayed for optometry with no definite date for implementation. Fostering a public health approach to training optometrists requires much time and input from key educators and curriculum designers. In this context, it is evident there is need for short-term strategies to attract recent graduates to the public sector and to retain the present public sector cadre.

\section{KwaZulu-Natal province and optometry}

KwaZulu-Natal (KZN) is one of nine provinces in South Africa, and with a population of $10.6 \mathrm{~m}$ people spread across 11 health districts, it is the largest and most populated province. ${ }^{31}$ In terms of HRs for eye health, the province has only recently (relative to medicine and other allied health professions) developed its public sector optometry systems. Posts have been created by the Department of Health $(\mathrm{DoH})$ in several hospitals throughout the province. Presently, most district and regional hospitals have at least two optometrists who provide mainly refraction, spectacle and referral services. However, anecdotal evidence suggests there is a high level of mobility among public sector optometrists with staff not being retained for long periods of time, despite efforts by the DoH. A limited body of knowledge exists on practice trends of South African optometrists regarding public sector work. This study attempted to understand key interventions that could be implemented to retain optometrists and highlight recruitment factors for future government efforts.

\section{Methods}

The study included all optometrists working, at the time of the study, in public sector hospitals in KZN. It also included all district health co-ordinators (DCs) for respective health districts in the province. Ethical permission for this study was obtained from the Biomedical Research and Ethics Committee of the University of KwaZulu-Natal with additional permissions from the provincial $\mathrm{DoH}$, health district managers and DCs.

A questionnaire was distributed via post, email, fax and online survey to both optometrists and health co-ordinators within the KZN public health service. Items in the questionnaire included socio-demographics, training, education queries and rating of interventions to be prioritised for their retention. As the data collection ended, participants who had not responded were contacted and had the questionnaire completed telephonically. After questionnaires were returned and analysed for recurring themes, telephonic semi-structured interviews with selected optometrists (one from each health district) and district coordinators (one each from geographically diverse regions of the province) were conducted to further explore qualitative responses. Questionnaires were captured on MS Excel ${ }^{\circledR}$ software package and exported to Stata 12 for further analysis, which included frequencies and distributions, Fisher's Exact test ( $5 \%$ significance level) and odds ratios. For telephonic interviews, responses were recorded using QuickVoice ${ }^{\circledR}$ and then transcribed with verbal responses collated and categorised by recurring themes.

\section{Results Demography}

Of a total population of 51 public sector optometrists in $\mathrm{KZN}$, $41(80 \%)$ participated in the study, while a $75 \%$ (9 out of 12 ) response rate for was obtained for DCs.

Demographic profile of participants and their distribution are presented in Table 1. Optometrist's ages ranged from 22 to 45 years, with a mean age of $29.68( \pm 6.37)$ years. The gender ratio was approximately $1: 3$ with $37(66 \%)$ female optometrists, while racial distribution was 27 and $63 \%$ for Indian people and black people, respectively. Thirty-nine percent of participants were first-time employees. The majority of DCs were women $(78 \%)$ with ages ranging from 45 to 56 years and a mean age of $51( \pm 3.46)$ years. Forty-four percent of DCs were currently in their post for 7-9 years with over half (56\%) having a nursing background.

\section{Recruitment}

\section{Rural origin}

Fifty-three percent of optometrists reported their origin as rural. District co-ordinators believed that students with rural backgrounds had an inherent sense of community, and this influenced their decision to work in the public sector. This is apparent in:

'If one grew $[u p]$ in the community, socially, they are able to identify the needs of the community .... and thereafter [the student] decides to study and qualify to meet the needs of the community.' (VM, Male, 50)

Another remarked: 'students from rural areas like to make a difference in their own community'. Reactions were varied 
from other participants, with one district co-ordinator (MS, Female, 53) feeling that 'those coming from urban background find it difficult to adjust to rural life', while, another (LZ, Female, 53) felt that 'rural students prefer to work in town/city'.

\section{Prior exposure to community practice}

In interviews, $81 \%$ of optometrists noted the influence of public sector exposure in undergraduate training to their current mode of practice. One optometrist recalled:

'Outreach programmes, like Stanger [an eye clinic at a hospital for student's training], was the activity that introduced me to public sector optometry ... ignited my love for it. After Phelophepa [Health Care Train], in our final year, I knew that after I graduate, I want to go into public sector.' (SM, Female, 33)

One participant (NM, Female, 24), noted that 'third and final year clinical rotations made it easy to work in public sector and deal with patients'. District co-ordinators (VM, Male, 50) observed that graduated optometrists have 'extensive training and education at the various universities', while another (BM, Female, 50) noted, 'they are clinicians. [They've] examined patients on Phelophepa, University, Clinics, and Hospitals and have ... acquired adequate training to manage general eye health in the community'.

\section{Reasons for working in the public sector}

Responses were placed into several broad categories (personal, social, job related, education or training related

TABLE 1: Demographic profile of participants per health district of KwaZuluNatal.

\begin{tabular}{|c|c|c|c|}
\hline Category & $n$ & $\%$ & $p$ \\
\hline \multicolumn{4}{|l|}{ Age group (years) } \\
\hline$\leq 30$ & 30 & 73.2 & 0.003 \\
\hline$>30$ & 11 & 26.8 & \\
\hline \multicolumn{4}{|l|}{ Sex } \\
\hline Male & 14 & 34.2 & 0.042 \\
\hline Female & 27 & 65.9 & \\
\hline \multicolumn{4}{|l|}{ Population group } \\
\hline Black & 29 & 70.7 & 0.003 \\
\hline Indian & 12 & 29.3 & \\
\hline \multicolumn{4}{|l|}{ Origin } \\
\hline Rural & 22 & 53.7 & 0.639 \\
\hline Urban & 19 & 46.3 & \\
\hline \multicolumn{4}{|l|}{ First job } \\
\hline Yes & 16 & 39.0 & 0.160 \\
\hline No & 25 & 61.0 & \\
\hline \multicolumn{4}{|l|}{ District } \\
\hline Amajuba & 5 & 12.2 & 0.619 \\
\hline eThekwini & 8 & 19.5 & \\
\hline ILembe & 4 & 9.76 & \\
\hline Sisonke & 2 & 4.9 & \\
\hline Ugu & 4 & 9.8 & \\
\hline Umgungundlovu & 2 & 4.9 & \\
\hline Umkhanyakude & 3 & 7.3 & \\
\hline Umzinyathi & 4 & 9.8 & \\
\hline Uthukela & 2 & 4.9 & \\
\hline Uthungulu & 4 & 9.8 & \\
\hline Zululand & 3 & 7.3 & \\
\hline Total & 41 & 100 & \\
\hline
\end{tabular}

and private practice related). Participants were asked to rank the reasons for choosing to work in the public sector, being allowed to choose more than one option. The most frequent reasons were bursary or loan obligation $(53.7 \%)$, wanting to make a difference and good working hours $(51.2 \%)$, free weekends $(46.3 \%)$ and wanting to learn more $(46.3 \%)$. Table 2 ranks participant's reasons as per various categories.

\section{Retention}

Respondents were asked to rank the need for interventions related to their potential retention, that is, what will most likely influence them to stay in the public sector and how urgently are such interventions needed?

\section{Salary and other incentives}

Improving salaries was ranked the most needed with 98\% (40 out of 41) of responses. Optometrists mentioned a mean acceptable salary of R28726.39 ( \pm R8853.74) [ $\$ 1759.03$ ( \pm \$542.15)] per month given the current economic climate, with no association with demographic categories. Eight out of eleven participants benchmarked the salary of other allied health professionals (pharmacy, physiotherapy and radiography) to provide this figure. 'Physiotherapists on community service earn more than full-time optoms', one participant (ML, Female, 26) observed. Another (SM, Male, 30) reported 'We don't earn the same as other professionals with a 4 year degree; salary needs to be on the same scale'.

OSD has had little effect on improving the financial situation of optometrists. 'It [OSD] has not helped, over and above basic salary - the basic salary is too low to begin with', stated one optometrist (NM, Female, 30). The uneven implementation of RA was noted with one optometrist

TABLE 2: Ranking of reasons why optometrists choose to work in the public sector.

\begin{tabular}{|c|c|c|c|}
\hline \multirow[t]{2}{*}{ Category } & \multirow[t]{2}{*}{ Reason } & \multicolumn{2}{|c|}{ Frequency $(n=41$} \\
\hline & & $n$ & $\%$ \\
\hline \multirow[t]{5}{*}{ Personal } & Wanted to make a difference & 21 & 51.2 \\
\hline & Wanted to learn more & 19 & 46.3 \\
\hline & Bored with private practice & 6 & 14.6 \\
\hline & Curiosity & 2 & 4.9 \\
\hline & Self-realisation & 2 & 4.9 \\
\hline \multirow[t]{4}{*}{ Social } & Good working hours & 21 & 51.2 \\
\hline & Free weekends & 19 & 46.3 \\
\hline & Social recognition & 1 & 2.4 \\
\hline & Family tradition & 0 & 0.0 \\
\hline \multirow[t]{4}{*}{ Job related } & Job security & 14 & 34.1 \\
\hline & Job benefits & 11 & 26.8 \\
\hline & Better salary & 5 & 12.2 \\
\hline & Better career path & 2 & 4.9 \\
\hline \multirow{2}{*}{$\begin{array}{l}\text { Education or } \\
\text { training }\end{array}$} & Bursary or loan obligation & 22 & 53.7 \\
\hline & $\begin{array}{l}\text { Previous exposure to public sector } \\
\text { work in undergraduate studies }\end{array}$ & 9 & 22.0 \\
\hline \multirow[t]{4}{*}{ Private sector } & Could not afford to open your own practice & 11 & 26.8 \\
\hline & Less responsibility than private sector & 6 & 14.6 \\
\hline & More responsibility than private sector & 2 & 4.9 \\
\hline & Could not get a job in the private sector & 1 & 2.4 \\
\hline
\end{tabular}

$n=41$. 
(NS, Female, 24) noting that 'Physio's and radiographers are getting allowances and we are not', while another (AM, Male, 30) observed that 'unions want us to join to them to better represent us but there are so many unions'. For $42 \%$ of co-ordinators, salary expectations for optometrists should be from R22 567 (\$1381) to R45 833 (\$2806), with an average of R33 $210 \pm$ R10 $083(\$ 2033 \pm \$ 617)$ per month. Another co-ordinator (WM, Female, 53) mentioned that 'rural allowance and other [financial incentives] are a provincial directive', while another (JK, Female, age not given) noted that 'the facility's HR [Human Resource] Department is responsible for implementing any financial benefits to optometrists'.

\section{Career management}

With $85 \%$ of responses, career management was the second highest required intervention reported by optometrists. Regarding progression onto higher grades one optometrist (TM, Male, 25) felt 'it took too long to progress ... to move up grades - pharmacy is shorter. [There] needs to be consistency across allied health professions'. An emerging theme was the lack of understanding and implementation of performance management systems. These are noted by one optometrist (ML, Female, 26), 'The hospital has an EPMDS [Employee Performance Management and Development System] to evaluate us ... I had to design my own job description! How do I evaluate myself?', while another (RS, Female, 25) observed that 'according to my Manager - everyone gets a " 3 "' (a satisfactory performance rating on EPMDS).

\section{Recognition}

Recognition was rated as a necessary intervention for retention by $83 \%$ (34 out of 41 ) of optometrists. Two themes emerged from further discussion with participants. 'Recognition' was interpreted as either (1) recognition of the profession or (2) recognition of the individual. Responses which alluded to the former include (SM, Female, 33): 'We are not recognised as optometrists in the public sector' , '... we are not recognised; our place in the system is not understood. [We are] just used as refractionists'.

Regarding the individual, in some districts optometrists (LG, Female, 28) are 'recognised at award ceremonies, that includes the whole eye unit', and (SN, Female, 30) 'we are recognised by patients and receive praise from them in the community ...'. In other responses, recognition appears to be non-existent, with one optometrist (NS, Female, 24) noting, 'people do not even know that there is an eye unit at this hospital'. Interviews with district co-ordinators also revealed a lack of recognition of the profession, with one co-ordinator (BM, Female, 50) acknowledging that 'recognition needs to be addressed, as this hasn't happened much'.

\section{Good management}

This was the fourth highest rated intervention by $73 \%$ (30 out of 41) participants. Optometrists revealed varying experiences with managers and hospital management structures. One participant (AM, Male, 30) mentioned, '... I am only really engaged when the manager needs something from me'. Change in hospital reporting structure was shown to assist optometrists, as evidenced by the following statement:

'A new medical manager has picked up that we should not be reporting to ophthalmology but directly to the medical manager himself. This has made my life much easier ... I've been able to negotiate ... and we are now awaiting our own space for optometry separate from what ophthalmology is requesting.' (SM, Female, 33)

Eight out of eleven optometrists (72\%) enjoyed support from district co-ordinators. One participant noted:

'District co-ordinator A is very supportive and always offering advice. I talk to her when I need help ... There is also good communication, cc'ing me when she emails my manager.' (ML, Female, 26)

Another (TM, Female, 30) observed that 'there is good support from district co-ordinator B; he is able to co-ordinate well with other optoms ... We are very lucky to have district co-ordinator B ...'.

The remaining comments about district co-ordinators revealed perceived lack of knowledge of optometry needs (AM, Male, 30) : 'District Co-ordinator C does not know anything about eyes, equipment or what is needed. How will someone fight for you, if they don't know about eyes?'

\section{Improved infrastructure}

Improving equipment and infrastructure was the fifth highest priority rated by $71 \%$ of participants. There was an association between this intervention and age $(p=0.04)$ and also with race ( $p=0.02)$, with this being highest rated by optometrists under the age of $30(80 \% ; 24$ out of 30). Eighty percent of black participants also ranked this factor as the highest. Eighteen percent reported satisfaction with equipment at their hospitals, 'but needed more space'.

Challenges with the ordering process occur, as evidenced by one optometrist: 'I do not have a trial frame at present, I submitted [a motivation] to my manager, who submitted to Cash Flow [Division in the hospital that requisitions equipment]. If they cannot obtain 3 quotes [for equipment], it has to go out on tender ... I'm still waiting; it's been under 2 years'. Another participant (AM, Male, 30) discussed that 'we use our equipment, but we really need tonometers to detect glaucoma'. Similarly, a participant (NS, Female, 24) commented that 'we have little equipment at present and can only refer. Glaucoma patients are not treated properly, not given the best service'.

Discussions with co-ordinators revealed historical challenges to this aspect. 'The District Office had [financial] allocations for all programmes. About $4-5$ years ago funding was taken away from our offices and we were told "funds are where service happens"' (BM, Female, 50). From this statement, 
control of budgets was removed from District offices and given solely to the hospital facility. The effect of this decision is noted in the following statement made by a co-ordinator:

'Motivations [for equipment] are made to the medical committees. Due to the Public Financial Management Act, you need a committee to make decisions. It depends on individual committees - some work slowly; some are fast.' (BM, Female, 50)

\section{Continuous professional development}

Two out of eleven participants (18\%) mentioned regular CPD activities at their hospitals through a regular 'journal club' (challenging clinical cases and how they were treated are shared with other eye health professionals). Remaining optometrists expressed challenges with attending CPD activities. 'We are expected to attend conferences to learn more ... but are not given days off to attend; we have to take leave days', noted one participant (ML, Female, 26). In other hospitals, optometrists (FM, Female, 25) reported 'we are given leave for CPD workshops, but no transport, accommodation ... we have to support ourselves'.

\section{Future plans}

Optometrists were asked to indicate their intention to stay in their current institutions over the next $3-5$ years. If they could not see themselves at their institutes, they were asked why and what alternate forms of employment would they seek. Table 3 describes the profile and future plans of optometrists working in the public sector.

TABLE 3: Profile and intentions of public sector optometrists over the next 3-5 years.

\begin{tabular}{|c|c|c|c|c|c|}
\hline \multirow{2}{*}{$\begin{array}{l}\text { Do you see yourself at your } \\
\text { current institution in the next } \\
3-5 \text { years? }\end{array}$} & \multicolumn{2}{|c|}{ Yes $(n=18)$} & \multicolumn{2}{|c|}{ No $(n=22)$} & \multirow[t]{2}{*}{$p$} \\
\hline & $n$ & $\%$ & $n$ & $\%$ & \\
\hline \multicolumn{6}{|l|}{ Age } \\
\hline$\leq 30$ & 11 & 61 & 19 & 86 & 0.14 \\
\hline$>30$ & 7 & 39 & 3 & 14 & \\
\hline \multicolumn{6}{|l|}{ Gender } \\
\hline Male & 5 & 28 & 9 & 41 & 0.51 \\
\hline Female & 13 & 72 & 13 & 59 & \\
\hline \multicolumn{6}{|l|}{ Population } \\
\hline Black & 8 & 44 & 21 & 95 & 0.01 \\
\hline Indian & 10 & 56 & 1 & 5 & \\
\hline \multicolumn{6}{|l|}{ Origin } \\
\hline Rural & 7 & 39 & 14 & 63 & \\
\hline Urban & 11 & 61 & 8 & 36 & \\
\hline \multicolumn{6}{|l|}{ Work history and experience } \\
\hline First-time employee & 6 & 40 & 9 & 60 & 0.75 \\
\hline Previously employed & 12 & 48 & 13 & 52 & \\
\hline \multicolumn{6}{|l|}{ Reasons for exiting current job } \\
\hline Career management & - & - & 7 & 21 & - \\
\hline Salary & - & - & 7 & 21 & \\
\hline Equipment or infrastructure & - & - & 5 & 15 & \\
\hline Working conditions & - & - & 4 & 12 & \\
\hline Recognition & - & - & 4 & 12 & \\
\hline Personal reasons & - & - & 3 & 9 & \\
\hline Management relations & - & - & 2 & 6 & \\
\hline Study further & - & - & 1 & 3 & \\
\hline $\begin{array}{l}\text { Continuous professional } \\
\text { development }\end{array}$ & - & - & 1 & 3 & \\
\hline
\end{tabular}

At least 22 (54\%) participants could not see themselves working at their institution. Most commonly cited reasons ranged from lack of career management and poor salary $(21 \%)$ to poor equipment or infrastructure $(15 \%)$ and lack of recognition $(12 \%)$. An association between race $(p=0.00)$ and hospital level $(p=0.00)$ exists with $90 \%$ of Indian people (10 out of 11) and all (100\%; 2 out of 2) participants reporting choosing to leave after $3-5$ years of service.

Optometrists were asked about their future plans if they were to leave their current jobs. Commonly occurring responses included further study in a non-optometric field (59\%), fulltime private practice $(46 \%)$, academia $(20 \%)$, postgraduate studies (20\%) and not practicing optometry (22\%).

\section{Discussion Demography}

The study found $66 \%$ of the sample to be female and $34 \%$ male optometrists, with a male-to-female ratio of approximately 1:3. While there is a paucity of data on gender profiles of graduated South African optometrists, this study is similar to profiles of optometry students that also suggest more female students. ${ }^{32}$ This could be attributed to the post-apartheid government's strategy to redress gender imbalances in higher education ${ }^{33}$ or due to female students taking more interest in optometry or better entrance results than male students, hence given greater priority for admission. ${ }^{34}$ Lastly, if there are proportionally more female students in optometry schools, it may be logical to assume that there will be more female students in the public sector.

This study found that mainly black people (73\%) and Indian people $(37 \%)$ comprised the sample. Historically, the School of Optometry at UKZN, has been training mainly black and Indian optometrists since the programme's inception in 198035; thus, a larger representation of these population groups is expected. Most conspicuous is the lack of white and mixed-race optometrists in public service in KZN. At a national, university and optometry school level, small enrolment numbers of these racial groups have been noted. ${ }^{32,34}$ As one of the provinces with a small mixed-race population, it can be logical to assume that there will be a low uptake within UKZN optometry. With proposed compulsory community service for graduating optometrists looming, and anecdotal plans to start a school of optometry in the Western Cape, this may increase the number of mixed-race graduates, creating a potential supply for the public sector.

The majority (73\%) of participants were under 30\% and 39\% first-time employees. While there appears to be no global trend in age profiles of health workers, ${ }^{1}$ findings in this study are contradictory to demographics of Zambian rural health workers $^{36}$ (26\% under 30 years) and South African nurses (4\% under the age of 30). ${ }^{37}$ Professionals under 30 and first-time employees are statistically associated with those who have chosen to work in the public sector due to bursary or loan obligations. It would appear that the introduction of study bursaries has led to a cadre of public sector optometrists who 
are largely young, economically mobile and relatively clinically inexperienced. These characteristics could impact on service delivery, while mobility could impact on sustainability of the service, if after loan obligations have been met there is a mass exodus of professionals. Furthermore, the present sample is a mix of multi-generational professionals Millennials (born between 1980 and 2000) and Generation X's (born between 1963 and 1980). HR managers need to be cognisant of these characteristics as career pathways, workforce motivation, recruitment and retention strategies are known to differ across generations. ${ }^{38}$

\section{Recruitment}

Fifty-three percent of participants in the public sector were of rural origin. Some have suggested that students of rural origin are more likely to return to a rural career. ${ }^{39}$ In contrast to studies of South African doctors ${ }^{39}(41 \%)$, this investigation found a higher percentage of rural origin students practicing in a public sector setting.

Mashige $^{34}$ and Boadi-Kusi ${ }^{40}$ found $73 \%$ and $79 \%$ of optometry students of urban origin in South Africa and Ghana, respectively. If optometry schools are a potential supply of public sector optometrists, review of origins of selected candidates may be warranted. In this study, the difference between UKZN optometry school profile and the public sector profile is significant for future retention strategies, as it does appear that rural students return to these areas to practice. District co-ordinators have suggested that some rural students can identify with communities, choose to work in rural areas, while some rural students prefer to work in urban areas. Conversely, it was found that urban students may find it harder to adjust and may not work longer than the length of their bursaries. ${ }^{41}$

Reasons for choosing an optometry career in South Africa are similar in Saudi Arabia ${ }^{42}$ and Ghana ${ }^{40}$ - a desire to help others and job availability were the most commonly expressed motives. In interviews, it emerged that exposure to clinical role models (visiting optometrists with parents, volunteering with an optometry student, for example) had some influence on their career choice - corresponding with studies of young doctors $^{43}$ and clinical nurses. ${ }^{44}$

A sense of altruism ('wanting to make a difference') and knowledge advancement ('wanting to learn more') were reasons for choosing to work in the public sector - appearing to parallel reasons given by ophthalmologists. ${ }^{45}$ 'Good working hours' and 'free weekends' were highest rated motivations from a social perspective. It could be that the regular working hours of state institutions, lack of clinical rotations and lack of work on weekends, unlike public sector doctors or nurses, is attractive to optometrists. From a jobrelated perspective, 'job benefits' were selected by the majority of participants in this category. DoH employees are known to receive medical aid contributions, home loan allowances, paid-leave days and service bonuses. ${ }^{46}$ While there is little or no data on workplace benefits as retention for eye health personnel, a systematic review of job satisfaction among nurses found such benefits to contribute to overall job satisfaction. ${ }^{47}$

Bursary and loan obligations were the most common reason for choosing public sector work for $53 \%$ of the respondents. Districts support students through their studies, and students are expected to serve in the district through a 'year for year work back agreement'. The use of bursaries for students of rural origin has been documented and applied as a method to increase rural health professionals, but the long-term effect on the rural health workforce is not clear. ${ }^{12}$ Future research efforts should focus on this aspect.

\section{Retention}

Improving salaries was the highest ranked intervention needed to retain KZN optometrists in the public sector. Given occupational specific dispensation additions, salaries for entry-level optometrist are approximately R211 902 (\$12 975) per year or R18 491 (\$1132) per month. ${ }^{48}$ When asked to comment on what would be an ideal salary, an average of R10 000 (\$612) per month more than the present salary emerged.

With South Africa's Consumer Price Index on the rise over the last 5 years, ${ }^{49}$ financial pressure has been placed on all consumers, including public sector optometrists. In comparison to other professions in the same Grade (Grade 1) Pharmacy salaries begin at R464 241 (\$28 427) or R38 686 (\$2368 per month), a higher salary level does exist, but includes the additional RA. Optometrists were not considered on the initial round of RA recipients and Health Trade Unions are still negotiating to have them included. The disparity in salaries between allied health professionals (physiotherapists, pharmacists, optometrists) is apparent, which lobbying and advocacy through professional associations or public sector forums can try to reduce. In terms of salary expectations, responding DCs felt that optometrists should be earning an average of R398 508 (\$24 402) per year or R33 209 (\$2033) per month. This is some R15 000 (\$919) more than the present Grade 1 salaries and approximately R5000 (\$306) more than the ideal salary suggested by optometrists. It was shown that RAs alone do not translate to improved retention, but a combination of financial and non-financial incentives would aid retention..$^{50}$ Further investigation comparing public sector salaries and benefits with those of the private sector may be beneficial to provide some form of benchmarking of the profession.

Career management and other HR functions occur at the facility level, with the District office supporting and guiding the process. It would appear that the devolution of certain HR processes to the facility level has effects on performance management and ultimately career pathways of optometrists. To this end, it would be imperative for DCs to engage facility-level HR and managers to ensure that optometrists' career needs are monitored and developed. The KZN Provincial Administration advocates a HRM framework 
that includes induction, career progression tracking and performance management. ${ }^{51}$ This study finds varied degrees of implementation of this framework, with a recommendation that HR departments revisit this HRM framework and provide appropriate induction and training to managers and optometrists alike.

The WHO global policy recommends recognition of health staff to improve retention. ${ }^{13}$ Public recognition activities such as health days and awards and titles create conditions to increase motivation of staff and contribute to their retention. From a professional perspective, some participants do not feel that they are being fully utilised. The Global Competency-Based Model of Scope of Practice in Optometry ${ }^{52}$ defines three broad areas (optical technology, ocular diagnosis and ocular therapy), over and above refraction, within which optometrists can participate. Awareness and implementation of this greater scope of practice by hospital and district management might ensure increased utilisation of optometrists.

District co-ordinators acknowledge that recognition of optometrists needs to be prioritised. It is up to the individual facility to appropriately budget and market eye health services to the community. Some co-ordinators feel that optometry should share the same status as other allied health professions - both in support and in remuneration. The promotion of the professional status of optometry may require the interventions of several stakeholders, including universities, professional bodies and eye health non-profit organisations

Good management relations and leadership in improving health workforce motivation has been described. ${ }^{53}$ The present study finds varying degrees of both and limited personal and professional support. In some low-resources settings, some managers are not adequately trained to deal with staff and HR challenges. In other institutes, task-shifting assigns clinicians to managerial duties and thus may not have time or inclination to fully support staff. ${ }^{54}$ Irrespective of the situation, managers need to have adequate skills and support to deal with HR situations to ensure a motivated and supported workforce.

Interviews with optometrists reveal a bureaucratic process for budgeting and ordering that hampers the procurement of equipment. While budgeting and motivation occur at the institution level, DCs encourage optometrists to engage managers to ensure equipment is timeously budgeted for using the proper channels. Patel ${ }^{55}$ noted that lack of equipment can be frustrating for eye care staff and have an impact on (1) their ability to deliver high-volume, highquality services, (2) their motivation and (3) their retention.

The Public Finance Management Act (No. 1 of 1999) passed in 2000 requires all government departments 'to ensure transparency and expenditure control, and to set the operational procedures for borrowing, guarantees, procurement and oversight over the various national and provincial revenue funds'.56 To align with this, hospitals and public sector departments have instituted procedures for the proper ordering, quotation and receiving of equipment. It is possible that these financial processes are implemented either inefficiently or officiously, as one district co-ordinator observed.

This study has found that there are financial and administrative issues that hamper optometrists from attending CPD workshops, conferences and activities. Regarding the financial aspect, there are several online platforms (such as Graduate Institute of Optometry, eyesite. co.za) that offer CPD points for optometrists thereby eliminating flight, transport and accommodation costs. In terms of the administrative challenges, it is recommended that these CPD activities are highlighted and linked with career pathway development. ${ }^{17}$ The outcomes from the CPD activity can increase the optometrist's skills and knowledge of patient care, making them better clinicians, which can subsequently enhance the clinical services offered at the different public sector institutes.

\section{Conclusion}

The profile of the currently serving public sector optometrists poses many HR challenges and opportunities. Universities appear to recruit a largely representative proportion of optometrists, but attention should also be given to the rural origin of candidates. Exposure to rural and public health training activities can serve as a catalyst for later career choices in the public sector. While Departments of Health use study bursary incentives to recruit health workers, much consideration needs to be given to financial (salaries comparable to other allied health professionals, RA) and non-financial incentives (career pathway development, recognition by management, improved infrastructure and CPD activities) to retain optometrists. Emphasis needs to be placed on HRM systems at the district and hospital level, with clear and wellarticulated programme planning and budgeting shared with clinicians and managers.

\section{Acknowledgements}

This article was adapted from a Master's thesis under the supervision of Prof. K. Naidoo. We thank all the optometrists and district co-ordinators for participating in the study and the KZN DoH for granting ethical permission. We also thank Ms Bukiwe Nqopiso (African Vision Research Institute) and all Sale Administrators (especially, the late Ms Thokozani Sibisi) at the Business Development Unit (Brien Holden Vision Institute) for assistance with data collection. We owe a large debt of gratitude to Mr Farai Chinanayi for his assistance with statistical analysis and reporting.

\section{Competing interests}

The authors declare that they have no financial or personal relationships which may have inappropriately influenced them in writing this article. 


\section{Authors' contributions}

P.R. was the principle investigator, implementer of the study and lead author. P.G. was co-author and K.N. was senior author.

\section{References}

1. World Health Organization (WHO). The World Health Report 2006: Working together for Health [serial online]. 2006 [cited 2010 May 1]. Available from: http://www.who.int/whr/2006/en

2. Clemens MA, Pettersson G. New data on African health professionals abroad. Hum Resour Health [serial online]. 2008 [cited 2009 Apr 23]. Available from: http://www.human-resources-health.com/content/6/1/1

3. World Health Organisation. A universal truth: No health without a workforce [serial online]. 2014 [cited 2015 Dec 4]. Available from: http://www.who.int/ workforcealliance/knowledge/resources/GHWA-a_universal_truth_report.pdf

4. Meyer $M$, Kirsten $M$, editors. Introduction to human resource management. Cape Town: New Africa Books; 2005.

5. Grobler LA, Marais BJ, Mabunda SA, Marindi PN, Reuter H, Volmink J. Interventions for increasing the proportion of health professionals practising in rural and other underserved areas. Cochrane Database Syst Rev [serial online] 2009 [cited 2014 Jul 17]. Available from: http://www.ncbi.nlm.nih.gov/pubmed/ 1916025

6. Fryer GE Jr., Stine C, Vojir C, Miller M. Predictors and profiles of rural versus urban family practice. Fam Med. 1997;29(2):115-118.

7. World Health Organization (WHO). Department of Human Resources for Health Issue 2. Spotlight on statistics: Gender and health workforce statistics [serial online]. 2008a [cited 2014 Oct 01]. Available from: http://www.who.int/hrh/ statistics/spotlight/en/

8. Singaravelu $H$, White $L$, Bringaze TB. Factors influencing international students career choice: A comparative study. J Career Dev. 2005;32(1):46-59. http://dx.doi. org/10.1177/0894845305277043

9. Mullan F, Frehywot $S$, Omaswa $F$, et al. Medical schools in sub-Saharan Africa. Lancet. 2011;9771(377):1113-1121. http://dx.doi.org/10.1016/S0140-6736(10) 61961-7

10. Couper ID, Hugo JFM, Conradie H, Mfenyana K. Influences on the choice of health professionals to practice in rural areas. S Afr Med J. 2007;97(11):1082-1086.

11. Business Directory [serial online]. 2016 [cited 2016 Jan 7]. Available from: http://www.businessdictionary.com/definition/employee-retention.html

12. Wilson NW, Couper ID, de Vries E, Reid S, Fish T, Marais BJ. A critical review of interventions to redress the inequitable distribution of healthcare professionals to rural and remote areas. Rural Remote Health [serial online]. 2009 [cited 2012 Aug 18]. Available from: http://www.rrh.org.au

13. World Health Organization (WHO). Increasing access to health workers in remote and rural areas through improved retention [serial online]. 2010b [cited $2014 \mathrm{Apr}$ 28]. Available from: http://www.who.int/hrh/retention/guidelines/en

14. Mathauer I, Imhoff I. Health worker motivation in Africa: The role of non-financial incentives and human resource management tools. Hum Resour Health [serial online]. 2006 [cited 2011 Jan 16]. Available from: http://www.ncbi.nlm.nih.gov/ pmc/articles/PMC1592506/

15. Health Professionals Council of South Africa (HPCSA). Continuing professional development Guidelines for the health care professionals: January 2011 [serial online]. 2014a [cited 2014 Jul 16]. Available from: http://www.hpcsa.co.za/ Content/Docs/guidelines_2011.pdf

16. Tian J, Atkinson NL, Portnoy B, Gold RS. A systematic review of evaluation in formal continuing medical education. J Contin Educ Health Prof. 2007;27(1):16-27. http://dx.doi.org/10.1002/chp.89

17. Lehmann $U$, Dieleman $M$, Martineau T. Staffing remote rural areas in middle- and low-income countries: A literature review of attraction and retention. BMC Health Serv Res [serial online]. 2008 [cited 2012 Sept 19]. Available from: http://www. biomedcentral.com/1472-6963/8/19

18. Awases M, Gbary A, Nyoni J, Chatora R. Migration of health professionals in six countries: A synthesis report. World Health Organization WHO-AFRO DHS [seria online]. 2004 [cited 2014 June 28]. Available from: http://www.afro.who.int/dsd/ migration6countriesfinal.pdf

19. Hagopian A, Zuyderduin A, Kyobutungi N, Yumkella F. Job satisfaction and morale in the Ugandan health workforce. Health Aff. 2009;28(5):863-875. http://dx.doi. org/10.1377/hlthaff.28.5.w863

20. Molinari DL, Monserud MA. Rural nurse job satisfaction. Rural Remote Health [serial online]. 2008 [cited 2014 Aug 5]. Available from: http://www.rrh.org.au

21. Stevens GA, White RA, Flaxman SR, et al. Global prevalence of vision impairment and blindness magnitude and temporal trends, 1990-2010. Ophthalmology 2013;120(12):2377-2384. http://dx.doi.org/10.1016/j.ophtha.2013.05.025

22. Naidoo K, Gichuhi S, Basáñez MG, et al. Prevalence and causes of vision loss in sub-Saharan Africa: 1990-2010. Br J Ophthalmol. 2014a;98:612-618. http:// dx.doi.org/10.1136/bjophthalmol-2013-304081

23. International Agency for the Prevention of Blindness. VISION 2020 [serial online] 2014a [cited 2014 Dec 1]. Available from: http://www.iapb.org/vision-2020
24. Garms RC. The global initiative: Launch of vision 2020. Community Eye Health J. 1998;11(28):56-57.

25. World Health Organization (WHO). Towards universal eye health: A regional action plan for the western pacific (2014-2019) [serial online]. 2014 [cited 2016 Jan 18]. Available from: http://www.wpro.who.int/entity/blindness prevention/ info/towards_universal_eye_health_.pdf

26. South African Government. White Paper for the Transformation of the Health System in South Africa. South Africa - Towards a National Health System. Government Gazette [serial online]. 1997 [cited 2014 Jul 5]. Available from: http://www.gov.za/documents/index.php

27. Health Professionals Council of South Africa [serial online]. 2014a [cited $2014 \mathrm{Jul}$ 09] South Africa. Available from: http://www.hpcsa.co.za

28. Bridging the gap in South Africa. Bull World Health Organ [serial online]. [cited 2015 Dec 09]; 88(11):797-876. Available from: http://www.who.int/bulletin/volumes/ 88/11/10-021110/en/

29. Oduntan AO, Louw A, Moodley VR, Richter M, Von Poser P. Perceptions, expectations, apprehensions and realities of graduating South African optometry students. S Afr Optom. 2007;66(3):94-108.

30. Lecouna K. A situational analysis of the eye care programmes in the 53 health districts in South Africa in 2006. A Dissertation submitted in partial fulfilment of the Requirements of London School of Hygiene and Tropical Medicine for the Master's Degree in Community Eye Health [serial online]. [cited 2014 the Master's Degree in Community Eye Health [serial online]. [cited 2014
Jul 01] Available from: http://www.Ishtm.ac.uk/library/MSc_CEH/2006-07/ Jul 01] Availa

31. Statistics South Africa. Mid-year population estimates: 2014. South Africa [serial online]. 2014a [cited 2014 Sept 13]. Available from: http://beta2.statssa.gov.za/ publications/P0302/P03022014.pdf

32. Nirghin U, Ebrahim Khan N, Mashige KP. Institutional, gender and racial profiles of South African optometrists. S Afr Optom. 2011;70(3):123-128.

33. Odhav K. South African post-apartheid higher education policy and its marginalisations. SA-eDUC J. 2009;6(1):20-48.

34. Mashige KP, Oduntan OA. Factors influencing South African optometry students in choosing their career and institution of learning. S Afr Optom. 2011;70(1):21-28.

35. Mashige KP. Optometric education at Westville: Past, present and future. S Afr Optom. 2010;69(1):11-20.

36. Mutale W, Ayles H, Bond V, Mwanamwenge MT, Balabanova D. Measuring health workers' motivation in rural health facilities: Baseline results from three study districts in Zambia. Hum Resour Health [serial online]. 2013 [cited 2014 May 04];11:8. Available from: http://www.human-resources-health.com/content/ $11 / 1 / 8$

37. George G, Quinlan T, Reardon C. Human resources for health: A needs and gaps analysis of Human Resources for Health in South Africa. Durban: Health Economics and HIV and AIDS Research Division (HEARD) [serial online]. 2009 [cited 2013 Dec 3]. Available from: http://www.heard.org.za/heard-resources/2009\#journalarticles

38. Sherman R. Leading a multigenerational nursing workforce: Issues, challenges and strategies. Online J Issues Nurs [serial online]. 2006 [cited 2012 Oct 18];11(2). Available from: http://gm6.nursingworld.org/MainMenuCategories/ 18];11(2). Available from: http://gm6.nursingworld.org/MainMenuCategories/ ANAMarketplace/ANAPeriod
No2May06/tpc30_216074.html

39. de Vries E, Reid S. Do South African medical students of rural origin return to rural practice? S Afr Med J. 2003;93(10):789-793.

40. Boadi-Kusi SB, Kyei S, Mashige KP, Abu EK, Antwi-Boasiako D, Halladay AC. Demographic characteristics of Ghanaian optometry students and factors influencing their career choice and institution of learning. Adv Health Sci Educ [serial online]. 2014 [cited 2014 Sept 13];19(2). Available from: http://link. springer.com/article/10.1007\%2Fs10459-014-9505-9

41. Frehywot S, Mullan F, Payne PW, Rossa H. Compulsory service programme as a means of deploying and retaining health workers in rural, remote and underserved areas - A global analysis. Bull World Health Organ. 2010;88(5):364-370. http:// dx.doi.org/10.2471/BLT.09.071605

42. Ausman J, Javed A, Ahmed S, et al. Social factors influencing career choice in a medical school in the United Arab Emirates. Educ Med J [serial online]. 2013 [cited 2014 Oct 14]. Available from: http://www.eduimed.com/index.php/eimj/article/ view/16

43. Paice $E$, Heard S, Moss F. How important are role models in making good doctors? BMJ. 2002;325(7366):707-710. http://dx.doi.org/10.2471/BLT.09.071605

44. Perry RN. Role modelling excellence in clinical nursing practice. Nurse Educ Pract. 2009;9(1):3644.

45. Gedde SJ, Budenz DL, Haft P, Tielsch JM, Lee Y, Quigley HA. Factors influencing career choices among graduating ophthalmology residents. Ophthalmology. 2005;112(7):1247-1254. http://dx.doi.org/10.1016/j.ophtha.2005.01.038

46. Parliamentary Monitoring Group. National Department of Health Annual Report 2013/14 [serial online]. 2014b [cited 2014 May 8]. Available from: http://www. pmg.org.za/policy-documents/2014/09/30/national-department-health-annualreport-201314-0

47. Lu H, Barriball KL, Zhang $X$, While AE. Job satisfaction among hospital nurses revisited: A systematic review. Int J Nurs Stud. 2012;49(8):1017-1038. http://dx. doi.org/10.1016/j.ijnurstu.2011.11.009

48. Public Servants Association of South Africa. Public Health and Social Development Sectoral Bargaining Council (PHSDSBC): Resolution 4 of 2009 [serial online]. 2014 [cited 2014 Sept 09]. Available from: https://www.psa.co.za/phsdsbc-0 
49. Statistics South Africa. Inflation [serial online]. 2014b [cited 2014 Nov 21] Available from: http://beta2.statssa.gov.za/?page_id $=735 \&$ id $=3$

50. Chelule PK, Madiba S. Assessment of the effectiveness of rural allowances as a strategy for recruiting and retaining health professionals in rural public hospitals in the North West Province, South Africa: management of health care services. Afr J Phys Health Educ Recreat Dance. 2014;20(Suppl 1):84-90.

51. KZN Department of Public Works. Provincial policy framework on retention of employees in the workplace [serial online]. 2014 [cited 2014 June 16]. Available from: http://www.kznworks.gov.za/Vmenu/PolicyLegislation

52. World Council of Optometry. A global competency-based model of scope of practice in optometry policy development [serial online]. 2014c [cited $2014 \mathrm{Ap}$ 3]. Available from: http://www.worldoptometry.org/filemanageroot/site_assets/ governance_documents/global_competencies_model.pdf
53. Kotzee T, Couper ID. What interventions do South African qualified doctors think will retain them in rural hospitals of the Limpopo province of South Africa? Rural
Remote Health [serial online]. 2006 [cited 2014 Oct 22];6(3):581. Available from: http://www.ncbi.nlm.nih.gov/pubmed/16965219

54. Ferrinho P, Sidat M, Goma F, Dussault G. Task-shifting: Experiences and opinions of health workers in Mozambique and Zambia. Hum Resour Health [serial online]. 2012 [cited 2014 Jul 17]. Available from: http://www biomedcentral.com/ 2012 [cited 2014 Jul 17]. Available from: http://www.biomedcentral.com/

55. Patel D, Mercer E, Mason I. Ophthalmic equipment survey 2010: Preliminary results. Community Eye Health J. 2010;23(73):23-25.

56. National Treasury. Legislation - Public Finance Management Act - PFMA [seria online]. 2014 [cited 2014 Dec 05]. Available from: http://www.treasury.gov.za/ legislation/pfma/ 